\title{
Instructors' Perceived Effectiveness of Current Professional Development Programs at Taif University English Language Center
}

\author{
Tha'er Issa Tawalbeh ${ }^{1}$ \\ ${ }^{1}$ English Language Center, Taif University, Taif, Kingdom of Saudi Arabia \\ Correspondence: Tha'er Issa Tawalbeh, English Language Center, Taif University, Hawiyah, Building No. 7000, \\ P.O Box 888, 21974, Kingdom of Saudi Arabia. Tel: 966-599-234-100. E-mail: anasthaer@hotmail.com
}

Received: August 31, 2015 Accepted: October 12, 2015 Online Published: October 13, 2015

doi:10.5539/elt.v8n11p117 URL: http://dx.doi.org/10.5539/elt.v8n11p117

\begin{abstract}
The present paper aimed to explore the EFL instructors perceived effectiveness of current professional development programs run at Taif University English Language Center (TUELC) in Saudi Arabia, and to provide suggestions to improve the current situation of these programs. To achieve these purposes, the researcher tried to answer three questions. The first question investigated instructors' perceptions of current professional development programs offered at the end of each semester, and the second and third questions examined the instructors' possible reasons for agreement and disagreement with the items proposed in the questionnaire distributed to them, and the instructors' suggestions to improve the current situation of professional development programs. A questionnaire of 4- Likert Scale and open-ended questions were used to gather data from seventy six teachers. The collected data were analyzed in the form of descriptive statistics, and content analysis was used for the open-ended questions. The results of the first question indicated that instructors in general have a negative attitude towards the current professional development programs run at the English Language Center. They only expressed their positive attitude towards the domains of professional knowledge and assessment strategies on the ground that they were given the opportunity to be interactive participants during discussing these two domains. Other possible reasons for agreement indicated that instructors shared knowledge and experience during the sessions of the program. However, their possible reasons for disagreement with the other domains showed that their actual needs were not considered when developing the program; they were mainly passive listeners, and the presenters were not professional enough to handle certain topics. Also, there was not enough focus on practice where learners could seek solutions to problems relevant to their classroom situations. They suggested that a needs assessment should be carried out and electronic professional development would be a good alternative to traditional meetings. Based on the results, the researcher drew certain conclusions and recommendations.
\end{abstract}

Keywords: effectiveness, English as a foreign language (EFL), professional development, Taif University, English Language Center, Saudi Arabia

\section{Introduction and Theoretical Background}

\subsection{An Overview of Teachers' Professional Development}

With rapid change, demands for high standards and quality education, teachers find it necessary to update and improve their knowledge and skills. They need opportunities to develop professionally. These opportunities start with pre-service activities and continue with in-service learning.

In order for learners to get effective learning opportunities, teachers' professional development should be considered as a major goal in institutions' policies. Teachers' knowledge and skills should undergo an ongoing process of development benefiting from major relevant work, so that they can meet learners' needs and interests. Craft (1996) asserts that with the increasing complexity of modern times, education faces many challenges. Professional institutions and organizations should formulate plans to face the new demands in the field of education. Teachers should develop their competencies through preparation and training to improve students' learning so that they can meet the changes of modern times. It should be recognized that even after pre-service preparation and education, in-service programs are very important for professional development of teachers. This 
development starts with the individual, but teachers' institutions and organizations play a key role in providing opportunities for a continuing process of training. Craft believes that teachers have now a need to update and improve their skills through in-service training to meet the rapid changes of modern times and the demands of quality education.

Nicholls (2000) defines professional development as "the enhancement of knowledge, skills and understanding of individuals or groups in learning contexts that maybe identified by themselves or their institutions" (p. 371). According to Craft (1996), professional development covers a wide range of activities meant to develop the learning of teachers, who have completed their initial training. In addition, it can be used to describe moving teachers forward in knowledge or skills. "Professional development refers to all types of professional learning undertaken by teachers beyond the point of initial training"(P.6). He pointed out that teachers need professional development to improve their job performance skills, extend their experience for career development or promotion purposes, develop their professional knowledge, extend their personal or general education, promote job satisfaction, and enable them to prepare for change. Teachers, who undergo meaningful professional development experiences, are "better prepared to make the most effective curriculum and instructional decisions" (Vrasidas \& Zembylas, 2004, p. 326). According to Bradely (1991), professional development aims to make people valued in their job, enable them to work effectively, help them prepare for change, and make them feel competent to contribute positively to the development of the school.

Many educational researchers and practitioners argue that in order to improve student achievement, it is necessary to improve teacher quality. One way to do this is through sustained classroom-based professional development programs, which aim to improve teachers' knowledge, instructional practices, and pedagogical beliefs. These programs provide teachers with the opportunity to master new strategies for meeting everyday issues related to their classroom practices. (Craft, 1996; Sparks \& Hirsh, 2000; Vrasidas \& Zembylas, 2004; Lock, 2006). According to Fullan (2007), teacher professional development promotes school reform initiatives, student achievement, and educational improvement It includes a series of activities designed for teachers to improve their professional knowledge and skills in a continuous manner in order to develop their students (Guskey, 2000).

For Vij and Mathur (2000), teaching is a profession, and so teachers should work hard to improve and perfect their professional competencies so that they can provide students with better learning opportunities. Learning must be a lifelong learning process. They add that teachers should work hard on their professional growth. This could be in the form of keeping their knowledge of the subject they teach up-to- date through in-service programs.

Clark (1992) argues that it is the responsibility of teachers themselves to develop professionally. He argues that adult development is voluntary; no one can force a person to learn. In this case, they realize full value of it than when they are forced into a training situation where they have little to do. He added that each teacher is unique in important ways; it is impossible to create a single, planned program of professional development that will meet everyone's needs and desires. It is good to support teachers in following an approach to lifelong learning.

Jackson (1992) discussed what the term teacher development means. He argues that it is related to how individual teachers develop in the process of their careers. According to him, there are a number of ways to help teachers develop. This can be by letting them know how to teach or how to teach better. Another way is to improve the conditions under which they work such as reducing their teaching load, giving them more time for planning, few students and more aids. He added that teachers need help to adapt to the demands of work, which involves giving encouragement, support, sympathy, and respect.

As far as training and professional development are concerned, in-service training should be given priority. Chaurasia (2000) points out that in order for learners to develop and play competitive roles, efforts should be made for quality education for learners. One way is to develop teachers' knowledge and skills. He adds that teachers should perceive their role as professionals. Each teacher must formulate strategies that develop his/her teaching competencies so that the desired improvement in the field of learning can be achieved. So, professional development implies that teachers possess certain competencies needed in the practice of the profession. Sapre (2000) maintains that teachers can be professionals if they recognize their own roles. To be regarded as professionals, they have to be highly competent, responsible for quality education, and independent decision makers when performing their professional duties. They have to determine their own goals and plans, and assess their performance. By doing this, they will be successful as professionals who are able to provide students with 
better learning opportunities. Professional development of teachers should be given proper consideration so that they are better able to face the existing challenges of modern times. This development can be realized by in-service training.

\subsection{Needs Assessment for Professional Development}

Craft (1996) stated that teachers need opportunities that ensure relevance to their needs and practice. Teachers' needs should be identified first. Later, this development should be related to practice, and should be sensitive to teachers' individual learning styles and experiences. It can be assumed that the starting point when conducting a professional development program is the needs assessment, which guarantees its success and continuity. Researchers start with needs analysis to get a clear picture of the particular skills that teachers need throughout their practice of the profession (Rae, 1999; Tawalbeh, 2005). Rae (1999) maintained that professional development is essential to demonstrate congruence with what is expected from teachers in the classroom, to model a needs' analysis process in action, and to acknowledge their professional and personal knowledge and goals. After all, the format and content of any proposed training, support or development should meet the needs of the target teachers. These needs include trainees' background experiences, the degree of skill they teach, classroom practices and tasks they need, their characteristics, personal preferences and problems ( Combo and Clark, 1978; McDonough 1984; Hutchinson and Waters , 1987; Lee (cited in Al-Shdaifat, 1998). Breen, Candlin, Dam and Gabrielson (1989) further argued that training should focus on what is done in class discussion and learning experiences. So, programs should be based on what teachers know and do and what occurs in the classroom.

\subsection{Problem Statement and Objective}

As an EFL specialist in teachers' professional development, it has been noticed that the majority of EFL instructors complain about most of the professional development workshops offered at TUELC. They claim that the workshops are not appealing to them. They report that the majority of topics are not based on a careful assessment of their needs. They add that the time of the workshops is not suitable, and methods of delivering the sessions are monotonous and boring. In addition, some trainers are not professional enough to run interactive sessions where trainees play an active role. This paper aims to explore the instructors' perceived effectiveness of current professional development programs at TUELC, and to provide suggestions to improve the current situation.

\subsection{Research Questions}

This research paper attempts to answer the following questions:

1) What are the EFL instructors' perceptions of current professional development programs offered at TUELC?

2) What are the instructors' possible reasons for agreement and disagreement with items proposed in the questionnaire distributed to them?

3) What are the instructors' suggestions to improve the current situation of professional development programs?

\subsection{Significance of the Study}

The results of this study are expected to be significant to:

Quality Assurance and Development Unit at the English Language Center to follow up the instructors' suggestions related to the current situation of professional development programs offered at the Center.

EFL instructors to assess professional development programs in terms of developing them according to their professional development needs.

\subsection{Definition of terms}

The following terms will have the associated meaning whenever they appear in this paper:

Professional development: A set of teaching skills and practices EFL teachers need during their professional career.

Professional development programs: A series of workshops offered at the English Language Center and meant to develop EFL instructors' teaching competencies. These workshops are held at the end of each semester and last for a week. 
Teachers' needs: Areas of teaching competencies where EFL teachers find themselves in need of to grow professionally.

\section{Review of Related Studies}

Many studies provided evidence that professional development programs have a direct impact on developing teachers' competencies so that they are better equipped with the tools necessary for the profession (Touchston, 1997; Deringer, 1998; Walqui, 1998; Stonner, 1999; Al Saa'di, 2005; Eun \& Andrey, 2007; Crawford et al., 2008; Halim, 2008; Masters et al., 2010). Other studies stress the importance of the point that professional development programs are effective if they are based on assessment of the teachers' needs in the field (Qasaymeh, 1995; Al-Ansari, 1996; Al-Shdaifat, 1998; Al Saa'di, 2005; Wall, 2008; Gorsev, 2010; Raik \&Jelena, 2013; Yurdakul et al., 2014). The studies reported in this section highlight the effectiveness of professional development programs, and the importance of needs assessment when developing a professional development program.

\subsection{Effectiveness of Professional Development Programs for Teachers}

Touchton (1997) investigated relationships between teacher professional development training and teachers' perceptions of faculty involvement in the competency of shared -decision making (SDM). Professional development training was measured through four core skill areas: communication, problem- solving, team building and conflict resolution. Four hundred forty- nine teachers from 18 elementary schools in West Central Florida participated. The study findings indicated that teachers level of participation in SDM, years of teaching experience, and ethnic background were predictors of teachers' perceptions of faculty involvement in SDM. The study also revealed significant, positive relationships between teachers' training hours in the SDM core skill areas and their own competencies.

Deringer (1998) explored the impact of a professional development program for middle level educators on the teachers who participate, on their school, and on their school districts. Twenty- eight teachers from three middle schools participated in the program. Data collection consisted of document analysis, interviews and observations. The findings revealed that teachers became learners; teachers were challenged to think in new ways; teachers gained confidence and felt empowered, and they became willing to initiate change and overcome obstacles. The researcher concluded that this professional development program contributed to the teachers' personal and professional growth.

Walqui (1998) investigated what Specially Designed Academic Instruction in English (SDAIE) teachers need to know, how they learn it, and how in-service education can meet their needs. This study tried to answer three questions (1) How do teachers develop the understanding required to teach subject matter content to second language learners? (2) What role does in-service professional growth play in the development and application of this understanding? (3) What elements of this institute could be used in future SDAIE teacher development programs? The findings of the study revealed that the model was effective in studying the teachers' knowledge and development. In addition, those teachers who entered the in-service program with well- developed professional visions, a strong sense of self and well- articulated questions, profited most. The researcher recommended that we need to think of professional development as a complex and long-term process. Besides, strong efforts must be made to make instruction classes more attractive for teachers and to promote the best teachers in these classes.

Stonner (1999) examined if there were significant relationships between the perceived impact of pre-service experiences, in-service experiences and professional relationships and the perceived level of competencies among first- year, middle school teachers. Teacher participants were asked about their perceived level of competencies. The researcher found that training programs have a very positive effect on developing EFL teachers' competencies. These programs improve teachers' performance and thus increase students' achievement.

Al Saa'di (2005) investigated the perceptions of United Nations Relief and Works Agency (UNRWA) English language teachers in Jordan of their professional development. The study attempted to answer questions related to whether or not there are statistically significant differences in teachers' attitudes towards professional development, their evaluation of training programs, their self-evaluation, and their training needs attributed to qualification, teaching experience and gender. The researcher also tried to identify the teachers' suggestions for improving teacher training and professional development. The main results revealed that there were no statistically significant differences in teachers' attitudes towards professional development, their evaluation of 
training programs, their self-evaluation, and their training needs attributed to qualification, teaching experience and gender. The main suggestions for improving teachers' professional development included the need for providing teachers with more access to the Internet at school, longer training workshops and better implementation of research findings.

Eun and Audrey (2007) studied the impact of professional development programs for English as second language (ESL) teachers on their classroom practice. The researchers collected data by using questionnaires administered to 90 elementary and secondary teachers participating in ESL training programs. Results indicated that teacher efficacy and organizational support significantly predict level of professional development impact.

Crawford, Megan and Alicia (2008) examined the effects of professional development on teachers' use of sheltered instruction. The participants included 23 teachers over a span of two years. Teachers displayed increased knowledge of sheltered instruction as measured through structured interviews, and they increased their use of sheltered instruction as measured by classroom observations. The findings contribute to the research base on the impact of quality professional development in improving teachers' use of instructional techniques.

Halim (2008) investigated the effect of using a training program on improving teaching performance of Faculty. To achieve this aim, an observation checklist was developed. The research sample consisted of twenty four EFL student teachers. The results indicated there were significant differences between the mean scores of the EFL student teachers due to the effect of the professional development strategies based on the program. In addition, the program proved to have a large effect on the following teaching performance domains (classroom management, assessment and professionalism). In conclusion, the program proved to be effective in improving the student teachers performance.

Heather, Holtzman, Chaney, and Kassandra (2009) stated that the San Diego reform aimed to improve classroom instruction by focusing on building the capacity of teachers. The researchers examined practices of teacher professional development in the district and their impact on literacy instruction. Through examination of school staff's conceptions of what makes professional development effective, and detailed data on professional development experiences from 100 elementary teachers, they found that professional development that focuses on content and curriculum and that incorporates coaching is related to a higher frequency of this type of instruction.

Masters, Raquel, Laura, Sheralyn, and Michael (2010) examined the effect of online professional development (OPD) on teacher quality by improving teachers' knowledge and instructional practices, with the ultimate goal of improving student achievement. There were significant effects on changes in teachers' knowledge and instructional practices, as they related to the targeted goals in vocabulary, reading comprehension, and writing instruction. Liu and Robert (2014) further investigated opportunities and challenges of online professional development between English as foreign language (EFL) pre-service and in-service teachers. Seventeen EFL pre-service and six EFL in-service teachers at different schools were involved in a web-based discussion board that promoted knowledge construction and professional growth. Results revealed the potential of enhancing knowledge construction between individuals. The pre-service teachers gradually explored teaching issues and the in-service teachers became devoted to integrating the information being shared. Most teachers reported that they experienced collaborative interaction, reflective practice, and emotional support. Several difficulties seemed to prevent some teachers from frequently joining the community.

\subsection{Needs Assessment for Professional Development}

Many studies provided evidence that designing EFL courses and programs should be based on needs analysis. Qasaymeh (1995) surveyed the needs of the students of medicine for English in the Jordanian University of Science and Technology. He used questionnaires to collect data from teachers and students. The findings of the study indicated that the specific needs of students are better professional courses with more emphasis on speaking, listening skills and writing of papers and researches. The researcher recommended building ESP courses depending on the exact needs of students. Priority must be given to professional English language when designing English curricula to fulfill students' needs.

Al-Ansari (1996) studied the current in-service education and training programs for EFL teachers in Saudi Arabia. He investigated their needs as demanded by the Saudi taught curriculum, and identified the future EFL teachers' needs as perceived by teachers themselves, EFL inspectors and teacher trainers. The study tried to bridge the gap between the current in-service education and training provision and the target needs. The findings 
of the present study revealed that there was a gap between the current in-service education and training programs provided by the Ministry of Education and the perceived in service training needs.

Al-Shdaifat (1998) explored the professional and teaching needs of EFL teachers in order to design a training course based on these needs. He also attempted to measure the extent of the subjects benefit from this training program. The sample consisted of 210 teachers chosen randomly. A questionnaire was used to identify the teachers' needs and a classroom observation checklist to measure the subjects' benefit from the program. The results of the study indicated that almost all the teaching skills in the questionnaire (planning, teaching practice, evaluation classroom management and classroom research) were very important particularly those related to teaching procedures. Other skills were found to be important such as classroom management and evaluation. The researcher recommended that supervisors may benefit from teachers' needs in devising and improving teachers' training programs.

Al Saa'di (2005) investigated the perceptions of UNRWA English language teachers in Jordan of their professional development and recommended that UNRWA at North Amman Education Area should pay more attention to teachers' needs. Teachers need more time to reflect on their teaching practices, more chances for teamwork, fewer administrative responsibilities and longer training workshops.

Wall (2008) explored the support needs in the areas of language proficiency and teaching methodology of a group of Thai high-school English as Foreign Language. The researcher used a questionnaire and a semi structured interview to collect data. It was found that all these teachers still wanted more in-service training. More importantly, the teachers still had observable needs in both their English and their understanding of communicative lesson planning. These results suggest that while it is important to ask teachers what they need, they cannot tell us what they don't know, and more objective needs-assessment should also be conducted.

Gorsev (2010) investigated English as Foreign Language teachers' needs with regard to the curriculum they are teaching at a private university. 18 teachers participated in this study and data were gathered by means of semi-structured interview. The results revealed common problems and suggestions among the teachers concerning the curriculum and instruction. The researcher suggested that teachers' needs should be taken into consideration as much as students' needs during the design and implementation process of the language teaching curriculum and syllabus.

Tawalbeh (2012) studied the effect of an in-service training program on developing EFL teachers' competencies. He surveyed the teachers' needs and developed a training program based on these needs. The results of the needs analysis indicated that teachers are in need of seven categories of competencies: methods of teaching, evaluation, co-curricular activities, classroom management, and problem solving, planning and error correction.

Raik and Jelena (2013) conducted a needs analysis for teachers in Estonia to see if there is a need for additional in-service support. The need analysis was conducted by the structural survey method teachers. The need for in-service professional training depends on the professional profile of each school. In-service training and language support should be based on the needs of a particular school. The system of in-service teacher training should take into consideration all components of teachers' professional competences while offering additional in-service training and language support on a regular basis.

Yurdakul, Oner, Esra, and Derya (2014) evaluated the professional development program on web based content development (WBCD) designed by the Ministry of National Education (MoNE). The researchers used both questionnaires and interviews to collect data. The results showed that the program was designed without a need analysis, that teachers were reluctant to implement the program, and that teachers di not manage to prepare web based instructional materials. The study showed that the WBCD program could not meet its objectives, and the program was therefore found to be inadequate in encouraging teachers to integrate their instructions with technology.

To conclude, previous studies have discussed the effectiveness of professional development programs on developing teachers' skills. Other studies pointed out that these programs should consider teachers' needs when planned. In this study, the context is different in that the focus is on EFL instructor's perceived effectiveness of professional development programs run at TUELC. In addition, the method combines both quantitative and qualitative means through a questionnaire to examine instructors' perceptions and open ended questions which seek the instructors' possible reasons for agreement or disagreement with the items proposed in the questionnaire and their suggestions to improve the current situation of professional development programs under study. 


\section{Method}

This part summarizes the methodology used to collect and analyze data. It discusses how population and sample of the study were identified, validating the instrument and checking its reliability, study procedures, and statistical analysis used to analyze the study data.

\subsection{Population and Sample Selection}

The study population consisted of 140 male and female instructors teaching English in the first semester of the academic year 2014-2015. The questionnaire was distributed to a random sample of 100 instructors, and 76 responded to the questionnaire.

\subsection{Study Instrument}

The researcher developed a questionnaire used by Jo-An and Reigeluth (2011) to measure teachers' perceived effectiveness of professional development programs especially in relation to technology use and learner-centered instruction. It has been adapted to cover a wider range of professional development aspects. In addition, it has been extended to include open ended questions (See appendix A). A 4- Likert Scale ( $1=$ Agree, $2=$ strongly agree, $3=$ disagree, $4=$ strongly disagree) was used to explore perceived effectiveness of current professional development programs run at the English Language Center.

\subsection{Instrument Validity and Reliability}

It can be argued that the instrument is valid since it has been developed by experts in the field. However, five EFL specialists were requested to check if the items were appropriate and relevant to the context of professional development at TUELC. They suggested that other aspects of professional development could be added to include a wider range of professional development aspects. Besides, the instrument was checked for reliability; the checklist was distributed to $10 \mathrm{EFL}$ instructors. They were asked to respond to the questionnaire. It was then distributed to them again after two weeks. The results were analyzed and the correlation coefficient (Pearson) between the previous and post time was 0.88 . The Cronbach alpha reliability for the checklist was .86 .

\subsection{Study Procedures}

The researcher started with the approval of the director of the English Language Center to conduct the study and distribute the questionnaire to the EFL instructors during a session of the professional development program. The instrument was checked for validity and reliability. Having the consent of the instructors, the questionnaire was distributed and collected after being filled in by the participants. The researcher processed the results using the appropriate statistical methods to get the findings. Based on the findings, relevant conclusions and recommendations were drawn.

\subsection{Statistical Analysis}

Descriptive statistical analysis was used to answer the first question aimed at investigating perceived effectiveness of current professional development programs. The qualitative method was used to answer the second and third questions related to the instructors' possible reasons for agreement or disagreement with the items suggested in the questionnaire and their suggestions to improve the current situation of professional development programs.

\section{Results and Discussion}

To answer the quantitative question of the study related to the perceived effectiveness of the professional development program as seen by the instructors, Table 1 below shows the means, standard deviation and percentages of the instructors' responses to the questionnaire. 
Table 1. Means, Standard Deviation and Percentages of the Instructors' Perceptions of the professional development program

\begin{tabular}{|c|c|c|c|c|c|}
\hline \multirow[t]{2}{*}{ No. } & \multirow{2}{*}{$\begin{array}{l}\text { Criteria } \\
\text { Current professional development programs: }\end{array}$} & \multirow[t]{2}{*}{ Mean } & \multirow{2}{*}{$\begin{array}{l}\text { Std. } \\
\text { Deviation }\end{array}$} & \multicolumn{2}{|c|}{ Percentage } \\
\hline & & & & Agree & Disagree \\
\hline 1 & help me improve my pedagogical knowledge. & 1.69 & 1.03 & 73.68 & 26.32 \\
\hline 2 & help me create a technology-enhanced classroom. & 2.51 & 1.11 & 39.47 & 60.53 \\
\hline 3 & help me create a learner-centered classroom. & 2.33 & 1.01 & 42.11 & 57.89 \\
\hline 4 & $\begin{array}{l}\text { help me understand how teaching and learning change } \\
\text { when particular technologies are used. }\end{array}$ & 2.31 & 1.09 & 41.90 & 58.10 \\
\hline 5 & provide some technology integration ideas. & 2.47 & 1.01 & 35.53 & 64.47 \\
\hline 6 & help me improve my assessment strategies. & 1.68 & 0.89 & 78.95 & 21.05 \\
\hline 7 & $\begin{array}{l}\text { help me improve my classroom management } \\
\text { competencies. }\end{array}$ & 2.35 & 1.06 & 43.81 & 56.19 \\
\hline 8 & help me improve my error correction techniques. & 2.41 & 1.10 & 34.50 & 65.50 \\
\hline 9 & $\begin{array}{l}\text { discuss relevant issues of language teaching and } \\
\text { culture. }\end{array}$ & 2.51 & 1.08 & 36.51 & 63.49 \\
\hline
\end{tabular}

It is evident from the table above that instructors agree with only items one and six of the questionnaire regarding their perceptions towards the current professional development program run at the English Language Center, and they disagree with the other 7 items. $73.68 \%$ of participants believe that the professional development program help improve their pedagogical knowledge, and $78.95 \%$ agree the program help improve their assessment strategies. However, the instructors relatively disagree with the majority of the items describing the effectiveness of the program. Between 58\%- 64\% don't believe that the program has a major effect in aspects related to developing their competencies of technology use in the classroom. In addition, many of them don't find the program effective in issues related to learner-centeredness, classroom management, error correction, language teaching and culture. All in all, the instructors in general have a relatively negative attitude towards the current professional development program run at the English Language Center.

In order to shed light on the instructors' attitudes towards the program and discuss their responses, they were asked to indicate possible reasons for their agreement or disagreement with the aspects of the program indicated in the questionnaire. This would be an answer to question two of this research paper. As for the instructors' positive attitude towards pedagogical knowledge and assessment strategies, they stated that they received interactive sessions relevant to their classroom situations in these two domains of professional competencies. In addition, they stated that the program was generally beneficial as they had the opportunity to share knowledge and experiences with colleagues. In general, the instructors expressed a degree of agreement with certain aspects of the program. Here are some of their views:

Instructor A said, "The sessions helped me update my pedagogical knowledge, assessment strategies and classroom management techniques as the sessions were interactive".

Instructor B said, "The program helped me understand how to apply assessment tools effectively in my classroom".

Instructor C said, "The topic of assessment is relevant to our classroom situation".

Instructor D said, "The program helped get new insight in methods of teaching and assessment strategies".

Instructor E said, "I could really make use of some topics discussed in the program. I benefited from those that assured the importance of involving students in the learning process".

Instructor F said, "Some sessions provided a platform for discussing ideas and knowledge sharing"

Instructor G said, "We have had the chance to exchange experiences and get new knowledge with colleagues, which would help improve our performance". 
Instructor H said, "I have had the chance to exchange and share knowledge with colleagues to improve my skills. The sessions provided opportunities for us to share experiences and learn from each other".

Instructor I said, "I benefited from the program in terms of improving my professional abilities".

Instructor F said, "We are sharing ideas and experiences with one another as we discuss different matters, so it is natural to benefit from the program".

Instructor G said, "The program helped me recall what I have already known and added new ideas suggested by participants".

As far as the instructors' negative attitude towards seven domains out of nine, the main concern was related to developing a program based on their actual professional development needs. They also indicated that the program was implemented by trainers who were not professional enough to run interactive sessions where participants play an active role in discussing issues of concern. In addition, sessions did not focus on enough practice in terms of discussing specific techniques applicable to their classroom situations. Participants most of the time were passive listeners to presenters who played a dominant role during the sessions. In addition, many participants pointed out that the sessions about technology need more elaboration in terms of making them relevant to their classrooms. Here are some of the instructors' quotations expressing their negative attitude:

Instructor A said, "Most topics do not touch upon the actual needs we have to be aware of in order to address students' needs and interests".

Instructor B said, "I find many presentations discuss broad ideas. For example, it is important to motivate our students as motivation will improve learning. However, this is not followed by real examples of what we can apply in our classrooms to do this. What we need are techniques we can actually use in our context".

Instructor $\mathrm{C}$ said, "The sessions repeat themselves over and over. What we actually need is workshops where each is a participant, not a passive recipient. The focus should be on how to teach and not only knowledge of something".

Instructor D said, "The use of technology in teaching language has not been covered well in the program". He maintained that rooms are not equipped enough with technology. The ideas provided on technology do not help one create a technology enhanced classroom".

Instructor E said, "As I am unable to incorporate technology in my classroom, I found the information provided useless".

Instructor F said, "We need the practical aspect of issues discussed to be applied in the classroom'.

Instructor G said, "Most of the strategies discussed are inapplicable in our classrooms. We need techniques that help us deal with large classes".

Instructor H said, "The topics are repeated, and the time it too long to discuss the topic assigned to a presenter".

Instructor I said, "Some topics are presented in a traditional way, which made us feel bored. We need interactive sessions where we can share ideas".

Instructor J said, "I would rather suggest sessions on how to minimize teacher talking time and maximize student talking time".

Instructor K said, "We need to discuss how to improve the language of students having low level of English language proficiency".

Instructor L, said, "I don't find some of the sessions beneficial as they are presented by unprofessional trainers".

Instructor M said, "Many sessions are theoretical; they do not provide enough practical solutions relevant to our teaching experience.

Instructor N said, "We cannot apply most trends of teaching in our classes because of cultural barriers".

Instructor O said, "Classrooms are generally designed as lecture halls; they are not suitable for teaching language. So, the ideas discussed during the sessions remain theory".

As far as the instructors' suggestions to improve the current situation of the professional development program, they proposed that professional development programs should be based on their needs. They also suggested that presenters should be more knowledgeable and professional enough to run interactive sessions where participants 
play a more active role, and to discuss problems and relevant solutions to their classroom situations. Afterwards, there should be regular meetings to discuss success stories, challenges and opportunities for success. Others suggested taking the electronic trend of professional development into consideration to overcome time constraints.

Here are some of their suggestions:

Instructor A said, "Our professional development needs should be considered in advance. A needs assessment should be carried out before designing the topics for program to be implemented".

Instructor B said, "I think the program should focus on discussing problems relevant to our situation, especially those related to culture, classroom management and large numbers of students, and finding out common solutions to handle these problems".

Instructor $\mathrm{C}$ said, "There should be time for instructors to transfer knowledge to classroom and then meet to discuss challenges, good practices and opportunities for success".

Instructor D said, "We need more interactive sessions where we can play a more active role, not only being passive listeners to presenters".

Instructor E said, "The sessions need to provide practical solutions relevant to our classroom situations. Where is practice? The presenters most of the time were teaching and we were passive listeners".

Instructor F said, "Presenters should be more knowledgeable and professional enough in terms of their knowledge and experience".

Instructor G said, "There should be a shift into electronic professional development to overcome time constraints and the difficulty of fitting a large number of trainees in an inconvenient hall".

Instructor H said, "Our classes should be equipped with technology to benefit more from the discussion of issues related to technology".

\section{Conclusions and Recommendations}

The present paper investigated the instructors' perceived effectiveness of current professional development programs run at university level. It has been found that instructors have a negative attitude towards the program except for two domains on the ground that these two were handled in interactive sessions. In addition, the instructors had the opportunity to share knowledge and experiences during the sessions. The instructors' main concern was related to a program which should be based on their actual professional development needs. They also need to play a more active role where the focus is more on interaction. In addition, the instructors expressed their willing to have more focus on practice where they seek solutions to problems relevant to their classroom situations. This can be facilitated by trainers who are more professionally equipped with professional competencies. As shown above, they expressed their possible reasons for their positive attitude towards the two domains of professional knowledge and assessment strategies, and their justifications for their negative attitude towards the other seven domains of the professional development programs. Based on this, they had a number of suggestions to overcome their concerns in terms of developing programs based on needs, and offered by professional trainers who run interactive sessions. Based on the findings of the present paper, the researcher recommended that the Quality Assurance and Development Unit in the English Language Center should consider the instructors' concerns and suggestions to improve the current situation of professional development programs run at the English Language Center.

\section{Acknowledgments}

The researchers would like to acknowledge the contribution of the instructors who validated the study instrument and those who responded to the questionnaire. Special thanks also go to the colleagues who assisted in the manuscript preparation.

\section{References}

Al-Ansari, I. H. (1996). In-service Education and Training of EFL Teachers in Saudi Arabia: A Study of Current Provision and Future Needs. Dissertation Abstracts International- C57/03, p. 716.

Al Sa'di, I. (2005). An Investigative Study of the Perceptions of UNRWA English Language Teachers in Jordan of their Professional Development. Unpublished MA Thesis. The University of Jordan, Jordan. 
Al- Shdaifat, A. H. (1998). Building a Training Course Based on EFL Teachers' Needs. Unpublished MA Thesis, Yarmouk University, Irbid, Jordan.

Bradely, H. W. (1991). Staff Development. London: Falmer.

Breen, M., Candlin C., Dam L., \& Gabrielsen G. (1989). The Evolution of a Training Program. In Johnson, R. K. (ed.). The Second Language Curriculum (pp. 111-135). Cambridge: Cambridge University Press. http://dx.doi.org/10.1017/CBO9781139524520.010

Chaurasia, G. (2000). Educating the Educators. In G. Chaurasia, (Ed.) Teacher Education and Professional Organizations (pp. 13-28). Delhi: Authorspress.

Clark, C. M. (1992). Teachers as Designers in Self- Directed Professional Development. In A. Hargreaves, \& M. G. Fullan (Eds.), Understanding Teacher Development (pp. 75-84). Teachers College Press, Columbia University: New York.

Conroy, M. A., Clark, D., Fox, J., \& Gable, R. A. (2000). Building Competence in Functional Behavioral Assessment (FBA): Are We Headed in the Right Direction?

Craft, A. (1996). Continuing Professional Development: A Practical Guide for Teachers and Schools. London: Routledge.

Crawford, L., Megan, S., \& Alicia, B. (2008). Impact of intensive professional development on teachers' use of sheltered instruction with students who are English language learners. Journal of In-Service Education, 34(3), 327-342. http://dx.doi.org/10.1080/13674580801950816

Deringer, M. L. (1998). The Impact of a Professional Development Program Co-Developed by Middle School Teachers and College Faculty: A Qualitative Study of Teacher Initiated Change. Dissertation Abstracts International- A 59/10, p. 3790.

Eun, B., \& Audrey, L. H-B. (2007). Impact of an English as a Second Language Professional Development Program. Journal of Educational Research, 101(2), 36-48. http://dx.doi.org/10.3200/JOER.101.1.36-49

Fullan, M. (2007). The New Meaning of Educational Change (4th ed.). New York: Teachers' College Press.

Gorsev, I. (2010). A case study on needs assessment of English language teachers. Procedia Social and Behavioral Sciences, 2(2), 317-321. http://dx.doi.org/10.1016/j.sbspro.2010.03.017

Guskey, T. R. (2000). Evaluating Professional Development. Eyalet: Corwin Press. Inc. A Sage Publications Company.

Halim, S. (2008). The Effect of Using Some professional Development Strategies on Improving the Teaching Performance of English Language Student Teacher at the Faculty of Education, Helwan University in the Light of Pre-service Teacher Standards.

Heather, Q. E., Holtzman, D, Chaney, J., \& Kassandra R. (2009). Professional Development and Instructional Practice: Conceptions and Evidence of Effectiveness. Journal of Education for Students Placed at Risk, 14(1), 45-71. http://dx.doi.org/10.1080/10824660802715429

Hutchinson \& Waters, A. (1987). Interface English for Technical Communication. London: Longman.

Jackson, P. W. (1992). Helping teachers Develop. In A. Hargreaves, \& M. G. Fullan (Eds.), Understanding Teacher Development (pp. 62-74). Teachers College Press, Columbia University: New York.

Jo, A. Y., \& Charles, R. (2011). Creating Technology-Enhanced, Learner-Centered Classrooms: K-12 Teachers' Beliefs, Perceptions, Barriers, and Support Needs. Journal of Digital Learning in Teacher Education, 28(2), 54-62. http://dx.doi.org/10.1080/21532974.2011.10784681

Liu, M., \& Robert, C. (2014). Fostering Online Professional Development between EFL Pre-service and In-service Teachers: Affordances and Challenges. English Language Teaching and Learning, 38(2), 29-64.

Lock, J. V. (2006). A new image: Online communities to facilitate teacher professional development. Journal of Technology and Teacher Education, 14(4), 663-678.

Masters, J., Raquel, M., Laura, M., Sheralyn, D., \& Michael, R. (2010). The Effect of Online Professional Development on Fourth Grade English Language Arts Teachers' Knowledge and Instructional Practices. Journal of Educational Computing Research, 43(3), 355-375. http://dx.doi.org/10.2190/EC.43.3.e 
McDonough, J. (1984). ESP in Perspective: Practical Guide. London: Collin.

Qasaymeh, Y. A. (1995). Needs Analysis of English at the Medical School in the University of Science and Technology. Unpublished MA Thesis. Yarmouk University, Irbid, Jordan.

Nicholls, G. (2000). Professional development, teaching, and lifelong learning. The implication for higher education. International Journal of Lifelong Education, 19(4), 370-377. http://dx.doi.org/10.1080/02601370050110419

Rae, L. (1999). Using Evaluation in Training and Development. London, UK: Kogan Page.

Raik, K., Igor, K., \&d Jelena, R. (2013). Subject Area Teachers' Professional Competence Development Needs during the Transition to Teaching in a Second Language. Problems of Education in the 21 ${ }^{\text {st }}$ Century, 57(1), 111-123.

Sapre, P. M. (2000). Professionalization in Teacher Education. In G. Chaurasia (Ed.), Teacher Education and Professional Organizations (pp. 1-12), Delhi: Authorspress.

Sparks, D., \& Hirsh, S. (2000). A national plan for improving professional development. National Staff Development Council. Retrieved April 19, 2006, from http://www. nsdc.org/library/authors/NSDCPlan.cfm

Stonner, N. C. (1999). Middle Level Teacher Preparation and Support: First- Year Teachers' Perceived Competence and Influencing Factors (Teacher Preparation, Beginning Teachers, Pre-service, In-service). Dissertation Abstracts international- A 06/04, p. 1089.

Tawalbeh, T. (2012). EFL Teachers' Competencies: A Reflective Model, Lambert Academic Publishing: Germany.

Touchton, D. J. (1997). Looking Through the Lens of Teacher Professional Development: An Exploratory Study of Elementary School Teachers Perceptions of Their Involvement in Shared Decision Making. Dissertation Abstracts International- A 57/10, P.4219.

Vij, D. R., \& Mathur, B. M. (2000). Reinvigorating Teacher Education. In G. Chaurasia (Ed.), Teacher Education and Professional Organizations (pp. 80-96). Delhi: Authorpress.

Vrasidas, C., \& Zembylas, M. (2004). Online professional development: Lessons from the field. Education \& Training, 46(6/7), 326-334. http://dx.doi.org/10.1108/00400910410555231

Yurdakul, B., Oner, U., Esra, C., \& Derya G. (2014). Evaluation of a Professional Development Program on Web Based Content Development. Educational Sciences: Theory and Practice, 14(4), 1427-1428.

Wall, U. (2008). A Needs Assessment Interview: The Professional Development Needs of Non-native Speaking EFL Teachers in Thailand. Innovation in Language Learning and Teaching, 2(1), 47-64. http://dx.doi.org/10.1080/17501220802158800

Walqui, A. (1998). The Development of Teachers Understanding: In-service Professional Growth for Teachers of English Language Learners. Dissertation Abstracts International- A 59/06, p. 1984. 


\section{Appendix A}

\section{Dear colleagues,}

The researcher will carry out a study to examine the EFL teachers' perceived effectiveness of current professional development programs at Taif University English Language Center. For this purpose, the researcher seeks your points of view by filling out the questionnaire below.

Please note that your contribution will be used for research purposes only.

Your agreement is appreciated.

The researcher

\section{Part A: Perceived effectiveness of current professional development programs}

Key: A= Agree $\quad \mathbf{S A}=$ Strongly Agree $\quad \mathbf{D}=$ Disagree $\quad \mathbf{S D}=$ Strongly Disagree

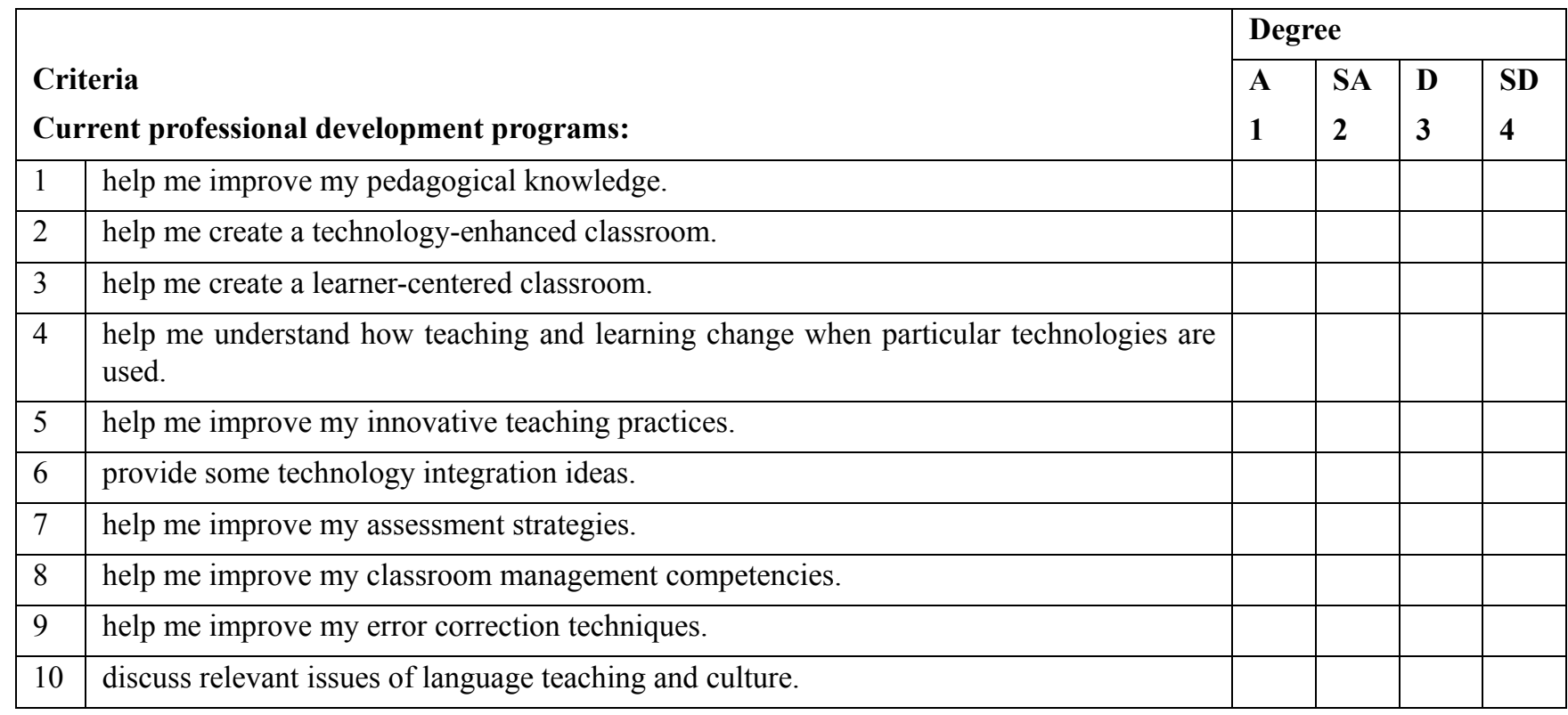




\section{Please see page TWO}

B. Please indicate below, your possible reasons of agreement or disagreement with the items stated in part A:

1- Possible reasons of agreement:

\section{2- Possible reasons of disagreement:}

C- Please suggest ways to improve the current situation of professional development program run at the English Language Center.

\section{Copyrights}

Copyright for this article is retained by the author(s), with first publication rights granted to the journal.

This is an open-access article distributed under the terms and conditions of the Creative Commons Attribution license (http://creativecommons.org/licenses/by/3.0/). 